Journal of Southeast Asian Human Rights, Vol.2 No. 1 June 2018. pp. 208-235

doi: $10.19184 /$ jseahr.v2i 1.7587

(c) University of Jember \& Indonesian Consortium for Human Rights Lecturers

\title{
Rejecting Religious Intolerance in South-East Asia
}

\author{
Benedict Rogers, Christian Solidarity Worldwide, United Kingdom
}

\begin{abstract}
South-east Asia is one of the most ethnically and religiously diverse regions of the world, and nowhere is more diverse in the region than Myanmar and Indonesia. In both countries, religious intolerance is rising, threatening respect for diversity. In Myanmar, Buddhist nationalism has grown in influence, empowered by support from the Myanmar military and the former governing party, the Union Solidarity and Development Party (USDP). Indonesia's tradition of religious pluralism, enshrined in the state ideology of Pancasila, which gives equal status to the country's recognized religions, is being threatened by the rise of radical Islamism. To stem the rise of intolerance and extremism, voices of moderation and pluralism championing the basic right of freedom of religion or belief from all perspectives and religious backgrounds are urgently needed.

The Rabat Plan of Action provides a helpful road-map for policy makers who aim to combat rising religious intolerance. It recognises that hate crimes are often rooted in cultural antipathy and the spreading of false information. Legislation is therefore only part of a larger toolbox needed to tackle hate speech. Important recommendations are made relating to the non-legislative policies of state and non-state actors. To challenge the hatred of extremists, a broad alliance which draws together lawmakers, the media, the international community, and civil society is required. To stem the rise of intolerance and extremism, voices of moderation and pluralism championing the basic right of freedom of religion or belief from all perspectives and religious backgrounds are urgently needed.

This paper will endeavour to apply the Rabat Plan specifically to the situations in Indonesia and Myanmar. Recommendations will call state actors, media and civil society to work together to combat hate speech narratives through all available channels: education, the judiciary, campaigning platforms, the media, legislation and international diplomacy.
\end{abstract}

Keywords: Religious Intolerance, Myanmar, Indonesia and Rabat Plan

\section{INTRODUCTION}

South-east Asia is one of the most ethnically and religiously diverse regions of the world, and nowhere is more diverse in the region than Myanmar and Indonesia. Myanmar has more than 130 ethnic groups and, although the majority population is Buddhist, has significant Christian, Muslim and Hindu communities. In Indonesia, Sunni, Shi'a, Sufi and Ahmadi Muslims live alongside Christians, Hindus, Confucianists and adherents of indigenous traditional religions and beliefs.

In both countries, religious intolerance is rising, threatening respect for diversity. In Myanmar, Buddhist nationalism has grown in influence, empowered by support from the Myanmar military and the former governing party, the Union Solidarity and 
Development Party (USDP). This has led to a campaign of hatred and violence, fueled by hate speech in Buddhist monks' sermons and on CDs, DVDs and leaflets widely distributed. Myanmar's Muslim population, both among the Rohingyas in Rakhine State and Muslims in the rest of the country, have been the principal targets, although Christians have also been affected.

Indonesia's tradition of religious pluralism, enshrined in the state ideology of Pancasila, which gives equal status to the country's recognized religions, is being threatened by the rise of radical Islamism. There have been violent attacks on Ahmadi and Shia Muslims, the closure of Christian churches, and tensions between the radicals and the predominant indigenous Sufi Muslim society.

The Rabat Plan of Action provides a helpful road-map for policy makers who aim to combat rising religious intolerance. ${ }^{1}$ It recognises that hate crimes are often rooted in cultural antipathy and the spreading of false information. Legislation is therefore only part of a larger toolbox needed to tackle hate speech. Important recommendations are made relating to the non-legislative policies of state and non-state actors. To challenge the hatred of extremists, a broad alliance which draws together lawmakers, the media, the international community, and civil society is required. To stem the rise of intolerance and extremism, voices of moderation and pluralism championing the basic right of freedom of religion or belief from all perspectives and religious backgrounds are urgently needed.

This paper will endeavour to apply the Rabat Plan specifically to the situations in Indonesia and Myanmar. Recommendations will call state actors, media and civil society to work together to combat hate speech narratives through all available channels: education, the judiciary, campaigning platforms, the media, legislation and international diplomacy.

In 2015 Christian Solidarity Worldwide organised the Myanmar-Indonesia Interfaith Exchange which drew together Buddhists, Muslims and Christians from Myanmar and Indonesia and civil society activists from both countries. The Wahid Foundation noted recently that there has been a rise in similar initiatives which promote religious tolerance in Indonesia. ${ }^{2}$ Although religious intolerance might appear to be an unstoppable force in both Indonesia and Myanmar, the majority population can be mobilised to promote peace and tolerance. This paper will use the Rabat Plan to explore pathways for that mobilisation.

\section{RELIGIOUS INTOLERANCE IN MYANMAR AND INDONESIA}

The most basic human right, besides that of life itself, is the freedom to choose, change, practice and share your beliefs. That means the freedom to adopt a religious faith, change your faith, or have no faith. It means the freedom to practice your beliefs, within the rule of law and in a way that is respectful of others, and the freedom to share your

Human Rights Council, United Nations Rabat Plan of Action, A/HRC/22/17/Add.4 (2013).

2 Margareth S Aritonang, "Religious-based discrimination lives on, but more positive initiatives grow: Wah...”, (28 February 2017), online: Jkt Post <http://www.thejakartapost.com/news/2017/02/28/religiousbased-discrimination-lives-on-but-more-positive-initiatives-grow-wahid-foundation.html>. 
beliefs, non-coercively, with others. Faith is an affair of heart, soul and mind, and no government, no law and no other person has any mandate to deny that right. The only limits for the practice of freedom of religion or belief are those limits that apply to all basic freedoms - to ensure that your freedom does not violate another person's freedom or security.

Yet around the world, and in Southeast Asia, freedom of religion or belief, as set out in Article 18 of the Universal Declaration of Human Rights, is one of the most widely violated yet under-recognised rights. ${ }^{3}$ The perpetrators of such violations differ depending on context. In Myanmar, ultra-nationalist Buddhism motivates violence; in Indonesia, radical Islamists are the primary instigators.

\section{Myanmar}

In Myanmar, Muslims and Christians face a campaign of hatred led by a militant ultranationalist Buddhist movement which has resulted in several outbreaks of violence in the past five years. ${ }^{4}$ The predominantly Muslim Rohingya people have been the most severely victimized, enduring grave human rights violations which some international experts describe as 'ethnic cleansing', 'crimes against humanity' and potentially genocide. The United Nations is currently conducting an investigation.

But intolerance in Myanmar has also led to Muslims in the rest of the country facing discrimination, hate speech and sporadic violence. While Christians have been less severely persecuted, they too have faced serious violations of freedom of religion or belief, both at the hands of the military and, more recently, in some of the Buddhist nationalist hate speech.

Buddhist nationalism is the root of much of the animosity. A number of high profile groups promote it, $\mathrm{Ma} \mathrm{Ba}$ Tha most notably. The ideology is supported by highly respected and widely followed Buddhist monks and the military-backed opposition party, the the Union Solidarity and Development Party (USDP). A listening project by Oxford University and MIDO, and a study by C4ADS, have provided thorough analyses of anti-Muslim sentiment in Myanmar. ${ }^{5}$ Both found that stereotypes and prejudices against Muslims were common, and that survey participants described Muslims as 'violent, untrustworthy and devout.' ${ }^{6}$ These stereotypes are ingrained and are being reinforced by nationalist groups who are systematically attempting to marginalise Muslims and other religious minorities in order to protect the Buddhist 'sasana' (community). The existence of the stereotypes gives credence to hate speech

3 Universal Declaration of Human Rights, United Nations, 1948 [Universal Declaration of Human Rights].

4 Poppy McPherson, "Myanmar failing to stop spread of religious violence, UN envoy says", The Guardian (19 May 2017), online: <http:/www.theguardian.com/world/2017/may/19/myanmar-failing-tostop-spread-of-religious-violence-un-envoy-says>.

5 C4DS, "Sticks and Stones: Hate Speech Narratives and Facilitators in Myanmar", online: Burma Partnersh <http://www.burmapartnership.org/2016/02/sticks-and-stones-hate-speech-narratives-andfacilitators-in-myanmar $>$.

$6 \quad$ Ibid at 13. 
while also ensuring that news stories which may not technically be 'hate speech' are interpreted through anti-Islamic lenses and thus perpetuate discrimination.

Muslims are understood to be an existential physical threat and a threat to religious sanctity. Nowhere is this more clearly seen than in Rakhine State where the rift between the Rakhine Buddhist community and the Rohingya Muslim community has left Rakhine effectively as an apartheid state.

The plight of the Rohingyas is the most acute and grave example of religious intolerance in Myanmar. Described as among the most persecuted people on earth, the Rohingyas have endured policies of marginalization, dehumanization and persecution for decades, particularly since the introduction of the 1982 Citizenship Law which stripped them of their citizenship rights and rendered them stateless. Even their name 'Rohingya' is not recognized by the State and to use the term in wider Myanmar society provokes passionate hostility. Hated by their Rakhine Buddhist neighbours, the Myanmar government and military claim that the Rohingyas are in fact illegal Bengali immigrants. But Bangladesh doesn't recognize them. As some Rohingyas say, "We are trapped between a crocodile and a snake."7

Violence broke out against the Rohingya in June 2012, and again in October 2012, resulting in thousands displaced and many killed. Since then, those who have remained in Myanmar have existed in dire conditions in camps in Rakhine state, but thousands have fled to Bangladesh or by boat to other parts of Asia, notably Thailand, Malaysia and Indonesia. ${ }^{8}$

In October 2016, failure to find a humane and just solution led a small group of Rohingyas to attack Burmese border police posts in October, killing nine police officers. This provoked the Burmese army into a grossly disproportionate response that has resulted in human rights violations which may amount to ethnic cleansing and crimes against humanity. ${ }^{9}$ John McKissick, head of the office of the United Nations High Commissioner for Refugees on the Bangladesh side of the border, has accused Burma's government of ethnic cleansing.

In December, 23 international figures, including 11 Nobel Peace Prize laureates and several former prime ministers, warned that the situation "has all the hallmarks of recent past tragedies-Rwanda, Darfur, Bosnia, Kosovo." They called for an independent UN inquiry to establish the truth, and the UN Human Rights Council subsequently established a fact-finding investigation. ${ }^{10}$

In February 2017, the United Nations issued a report on the Burmese military's abuse of Rohingya civilians in northern Rakhine State during the previous four

7 CSW, "CSW visit to the Bangladesh-Burma border - Christian Solidarity Worldwide", (26 August 2008), online: <https://www.csw.org.uk/2008/08/26/report/100/article.htm>.

$8 \mathrm{CSW}$, "CSW prioritise human rights during Burma trip - Christian Solidarity Worldwide", (7 December 2012), online: 〈https://www.csw.org.uk/2012/12/07/news/1366/article.htm>.

9 CSW, "Report on human rights violations in Rakhine State - Christian Solidarity Worldwide", (12 January 2017), online: 〈https://www.csw.org.uk/2017/01/12/report/3423/article.htm〉.

10 Oliver Holmes \& agencies, "Nobel laureates warn Aung San Suu Kyi over 'ethnic cleansing' of Rohingya", The Guardian (30 December 2016), online: <http://www.theguardian.com/world/2016/dec/30/nobel-laureates-aung-san-suu-kyi-ethnic-cleansingrohingya>. 
months. 11 The campaign of murders, mass gang-rapes, brutal beatings and disappearances clearly rises to the level of crimes against humanity. The report draws on interviews with 204 Rohingyas who fled to Bangladesh, most of whom witnessed killings. Almost half reported having a family member killed. Of the 101 women interviewed by UN investigators, more than half said they had been raped. Young children were killed in front of their parents. The UN has confirmed the equally graphic findings of investigators from private human-rights groups.

The High Commissioner for Human Rights Zeid Ra'ad Al Hussein said, "The devastating cruelty to which these children have been subjected is unbearable. What kind of hatred could make a man stab a baby crying out for his mother's milk? And for the mother to witness this murder while she is being gang-raped by the very security forces who should be protecting her-what kind of 'clearance operation' is this? What national security goals could possibly be served by this? . . . The killing of people as they prayed, fished to feed their families, the brutal beating of children as young as two and an elderly woman aged 80-the perpetrators of these violations, and those who ordered them, must be held accountable."

Since this paper was first written, the crisis facing the Rohingyas escalated still further, with an even more brutal and widespread campaign by the Myanmar military unleashed after the Arakan Rohingya Salvation Army (ARSA), a new Rohingya armed group, reportedly attacked border guard posts. In the campaign that followed, which the UN High Commissioner for human rights described as a 'text-book example of ethnic cleansing' and which the UN Special Rapporteur for Human Rights in Myanmar said had 'the hallmarks of genocide', over 700,000 Rohingyas fled to Bangladesh, precipitating the largest refugee crisis in the world today. Crimes against humanity including mass rape, burning of villages, beheadings, throwing babies into fires, and other killings have been reported.

Yet as devastating as the stories from the Rohingyas are, they are not the only Muslims targeted in Myanmar. Buddhist nationalists have waged a campaign of antiMuslim hatred across the country for the past four years. This led to outbreaks of violence and laws that restrict religious conversion and interfaith marriage, violating freedom of religion or belief.

Buddhist monks have made exacting, intense preaching tours in order to spread an anti-Muslim message. Their message is populist and extreme, and communicated to those across the social class spectrum. The Chairman of Ma Ba Tha, Ashin Tiloka is known for simple teaching style which makes complex Buddhist morals understandable to a wide audience. In June 2015 alone, U Wirathu preached an anti-Muslim message on 9 separate occasions. ${ }^{12}$ Hate speech has also been circulated through newspapers, magazines and television. Ma Ba Tha produce a number of low-cost, weekly publications. Aung Zeyathu is a weekly newspaper available at tea shops for 1,000 kyat (\$0.78), Atumashi is a magazine they publish for citizens of Upper Burma, and the

11 United Nations, "UN report details 'devastating cruelty' against Rohingya population in Myanmar's Rakhine province”, (3 February 2017), online: UN News <https://news.un.org/en/story/2017/02/550802un-report-details-devastating-cruelty-against-rohingya-population-myanmars $>$.

12 Burmese Muslim Association Situation Updates June 2015 
Myittatugun is a regular periodical which sells for 500 kyat. ${ }^{13}$ The rise of social media has added another forum of even greater significance. Facebook and other sites have been used as a platform to promote their agenda and sometimes spread slander and fake news. U Wirathu, the most well-known monk, had 264,906 followers on Facebook on 24 February 2017. Memes, videos or doctored images which show Muslims as dangerous rapists or terrorists are commonly widely shared. These images are crude and dehumanising, and yet are legitimised by the fact that religious leaders are willing to share them. This powerful multimedia campaign has spread hatred far and wide, justifying anti-Muslim policies and attitudes.

Restrictions against the construction of non-Buddhist places of worship have been in place since 1962, but in recent years the persecution has intensified in response to anti-Muslim fear-mongering. Several mosques have been burned down and many sealed by the authorities. On 21 April 2017, an ultra-nationalist Buddhist mob disrupted a prayer gathering by Muslims at an Islamic school in Rangoon, and a week later demanded that the police force the schools to close. ${ }^{14}$ On 29 May, Muslim leaders were summoned by the authorities to be informed that they were forbidden to use their residences for religious purposes. On 2 June, one man was charged for holding Ramadan prayers in the street for between 50-100 Muslims. ${ }^{15}$ He could face up to six months in prison.

These grinding restrictions might sound insignificant compared with the far more shocking mass violence unleashed against the Rohingyas and other Muslims throughout the country over the past five years, resulting in thousands of deaths and at least 150,000 displaced - many now facing a severe humanitarian crisis. But they are all part of the same picture - what starts with a mosque closure or an arrest for praying can quickly escalate into mob violence and ultimately mass murder.

This process from hate speech to violence was clearly seen in Meikthila and other townships around Myanmar in 2012-3, where Buddhist nationalists in the '969 movement' began by merely boycotting Muslim businesses, but then turned violent. ${ }^{16}$ The most serious example took place between 20 March and 22 March 2013, in Meikthila Township, Mandalay Division when Muslims in Meikthila were seriously attacked by a Buddhist nationalist mob after a false rumour about a rape incident was spread in the community. According to official figures, 12,800 people were displaced and 44 people killed. ${ }^{17} \mathrm{CSW}$ sources suggest that in reality 30,000 people had to flee their homes and around 200 were killed. These included children, some of whom were

13 C4DS, supra note 5 at 25.

14 Human Rights Watch (HRW), "Burma: Two Islamic Schools Shuttered in Rangoon”, (8 May 2017), online: Hum Rights Watch <https://www.hrw.org/news/2017/05/08/burma-two-islamic-schools-shutteredrangoon>.

15 Agence France-Presse, "Myanmar Muslims face charges for holding Ramadan prayers", The Guardian (2 June 2017), online: <http://www.theguardian.com/world/2017/jun/02/myanmar-muslims-face-chargesfor-holding-ramadan-prayers>.

16 Erika Kinetz, "New Numerology of Hate Grows in Burma", (29 April 2013), online: The Irrawaddy <https://www.irrawaddy.com/news/burma/new-numerology-of-hate-grows-in-burma.html>.

17 Altsean-Burma, "Anti-Muslim Violence in Central Burma”, (17 April 2013), online: Burma Partnersh <http://www.burmapartnership.org/2013/04/anti-muslim-violence-in-central-burma/>. 
burnt to death. Approximately 2000 million Kyats worth of property was destroyed. Twelve of the thirteen Mosques in the Township were destroyed. Five of these were burnt down. ${ }^{18}$ Today, 3000 people remain in IDP camps, and only five mosques have been allowed to be used for worship again.

Buddhist nationalism has fostered a culture of hatred and distrust in Myanmar. The violence it has stirred has only further divided communities. On 26 September 2016, a CSW contact interviewed 13 community members from the Buddhist and Muslim communities. One Muslim women described the ratcheted tension since the violent attacks: 'There have been no more direct attacks but there is a lot of tension, and hate speech continues in the town.'

The Burmese Buddhist nationalism which has fuelled intolerance against Muslims has also catalysed human rights violations against other ethnic and religious minorities. The same immunity the ideology grants to the Burmese military and mobsters in Rakhine or Meikthila has been given to the Burmese army as it has intensified its assault on the predominantly Christian Kachin ethnic group and other minorities in northern Shan State.

Thousands have been displaced in recent months, and a Catholic church was bombed in December. Two Kachin Christian pastors, Nawng Latt and Gam Seng, were arrested after taking journalists to the bombed church to gather evidence, and jailed under the Unlawful Association Act for allegedly aiding Kachin rebels, a charge they deny. ${ }^{19}$ They were released in April 2018. Even Lahpai Gam, a Kachin prisoner arrested by the Myanmar Army five years ago, whom the UN working group on arbitrary detention concludes is held arbitrarily and in violation of international law, was held in prison until April 2018. ${ }^{20}$ He was severely beaten from head to toe with an iron rod, forced to engage in sexual acts with another male prisoner, and forced to stand for hours with his arms outstretched as if being crucified. He has severe health problems as a result of the torture he endured, and human rights organisations are calling for his urgent release on medical grounds.

Religious intolerance is also found areas where peace-fire agreements have been signed. In the education system, programs are run by nationalists to indoctrinate children from a young age. Ethnic minority Christians are among some of the poorest inhabitants in Burma and there is a lack of educational provision which mean that many from Chin, Naga and other areas have been forced to send their children to $\mathrm{Na} \mathrm{Ta} \mathrm{La}$ schools. 9 of the 33 existing $\mathrm{Na}$ Ta La schools are in Chin State, and one third of $\mathrm{Na} \mathrm{Ta}$ La Trainees are ethnic Chin which indicates that they are specifically targeted. ${ }^{21}$ The Na

18 CSW Source.

19 Human Rights Watch, "Myanmar: Free Wrongfully Detained Kachin Christian Leaders”, (25 July 2017), online: Hum Rights Watch <https://www.hrw.org/news/2017/07/25/myanmar-free-wrongfullydetained-kachin-christian-leaders $>$.

20 Amnesty International, "MYANMAR: HEALTH CONCERNS FOR PRISONER OF CONSCIENCE: LAHPAI GAM", (7 April 2017), online: Amnesty Int <https://www.amnesty.org/en/documents/document/?indexNumber=asa16\%2f6029\%2f2017\&language=e $\mathrm{n}>$.

21 Rachel Fleming, Hidden Plight: CHRISTIAN MINORITIES IN BURMA (United States Commission on International Religious Freedom, 2016). 
Ta La school system was set up by the previous military regime, known as the State Peace and Development Council (SPDC), and exploits the poor education provision in order to indoctrinate young Christian children into Buddhism. Children at $\mathrm{Na} \mathrm{Ta} \mathrm{La}$ schools are systematically prevented from practicing Christianity and are effectively required to convert. The authorities bar church attendance and enforce compulsory Buddhist worship. Buddhist literature and culture is taught on Saturdays, and many children are forced to be initiated into monkhood for a period of each year. ${ }^{22}$ This school system generates animosity between Christian and their Buddhist counterparts, and is just another example of a culture which privileges the interests of Buddhists above those of other religions

Whether in Rakhine State, Mandalay Division, Chin State or Kachin State, Buddhist nationalism, along with the continuing impunity granted to the military, is fueling hatred and discord in Myanmar. It is the greatest existing threat to Myanmar's fragile democracy. Responding to the threat must be an urgent priority for Myanmar's government.

\section{Indonesia}

In Indonesia, a country with a tradition of religious tolerance, radical Islamism has become an increasing threat to non-Sunni Muslim minorities, particularly the Ahmadiyya and Shi'a communities, as well as Christians and other religions and to Sunni moderates who work to preserve Indonesia's pluralism.

With 260 million people, Indonesia is the world's fourth most populous nation, and the world's largest Muslim-majority population. ${ }^{23}$ A demographic study by the Pew Research Center's Religion and Public Life Project in 2012 concluded that 13\% of the world's Muslims live in Indonesia. ${ }^{24}$ An estimated $87.2 \%$ of the population is Muslim, while $7 \%$ is Protestant, 2.9\% Catholic, 1.7\% Hindu and 1.3\% belong to 'other' or 'unspecified' religions, which include Buddhism, Confucianism and unrecognised traditional indigenous beliefs. ${ }^{25}$

Prior to attaining independence in the early 20th century, there was a split among Indonesian Muslims over whether to ground the Indonesian constitution in Islamic law or pluralism. ${ }^{26}$ President Sukarno, Indonesia's founding father, maintained that religious minorities must have a stake in Indonesia's future. He proposed 'Pancasila' as Indonesia's foundational pluralistic philosophy. It consists of five points:

1. Belief in the one and only God

2. Just and civilised humanity

3. The unity of Indonesia

22 Ibid at 20.

23 United Nations Data, "UN Data, Indonesia”, online: UN Data <http://data.un.org/en/iso/id.html>.

24 Pew Research Center, "The Global Religious Landscape: Muslims", (18 December 2012), online: Pew Res Cent Relig Public Life Proj <http://www.pewforum.org/2012/12/18/global-religious-landscapemuslim/.

25 CIA, "CIA World Factbook: Indonesia", (4 June 2018), online: Cent Intell Agency <https://www.cia.gov/library/publications/the-world-factbook/geos/id.html>.

26 CSW, "Indonesia Report Pluralism in Peril - Christian Solidarity Worldwide", (14 February 2014), online: $C S W<$ https://www.csw.org.uk/2014/02/14/report/179/article.htm> at 25-26. 
4. Democracy led by the wisdom of deliberations among representatives

5. Social justice for the whole of the people of Indonesia.

The first principle was a compromise - a recognition that religion has a central place in Indonesian society, but a rejection of an explicitly Islamic state. It was an attempt to satisfy both religious conservatives and secularists. While in some respects it is restrictive, prescribing a belief in a theistic religion and thereby inherently discriminatory towards non-theistic or atheistic beliefs, its intention was to resist the imposition of Islamic law and protect religious pluralism. As the government explains, 'belief in the one and only God' means that "every Indonesian citizen, no matter which religious denomination or faith they follow, should respect each other's belief for the sake of the harmony and peace of mankind. This principle contains the precepts of religious tolerance and freedom of all to adhere to the religion or faith of his or her choice". 27

Pancasila has historically ensured peaceful co-existence between Indonesia's religious groups, and formed the basis of the 1945 constitution, which enshrines freedom of religion in Article 28(e). ${ }^{28}$

In recent years Indonesia's strong and proud pluralistic tradition, rooted in the heart of the constitution, has come under threat. CSW's report Indonesia: Pluralism in Peril - The rise of religious intolerance across the archipelago, published in 2014, provides detailed background on the situation of freedom of religion or belief and increasing violations over the past decade. ${ }^{29}$ It examines the record of the previous President, Susilo Bambang Yudhoyono, particularly several speeches in which he made remarks which can be interpreted as encouraging radical Islamists, and in particular legislative initiatives which have set the framework for the rise of religious intolerance, namely the 2006 Joint Regulation on Houses of Worship and the 2008 anti-Ahmadiyya Joint Decree. The report also examines abuses of the blasphemy laws set out in Articles 156 and 156 (a) of Indonesia's criminal code and in the 1965 Presidential Decree (No. 1/PNPS/1965) on the Prevention of Blasphemy and Abuse of Religions. Furthermore, the report details incidents of violence, abuse, discrimination and restrictions faced by Christians, Ahmadiyya, Shia, Buddhists, traditional indigenous beliefs and others. It concludes that: "Indonesia is at a crossroads, and if responsible actors both within the country and in the international community do not respond to these challenges effectively, Indonesia's pluralism will be in peril."

Since 2014 the situation has continued to deteriorate, although it is important to note that incidents of severe violence against minorities, particularly the Ahmadiyya, appear to have declined. As is referenced below, it is also important to commend President Joko Widodo's government for a change in tone, attitude and approach compared with the administration of President Susilo Bambang Yudhoyono. Nevertheless, on 10 January 2017, the Indonesian National Commission for Human Rights (Komnas HAM) published a report detailing a steady increase in FoRB

27 Ibid at 26-27.

28 AHRC, "The Constitution of the Republic of Indonesia of 1945", online: Asian Hum Rights Comm <http://www.humanrights.asia/countries/indonesia/\%20countries/indonesia/laws/uud1945_en>.

29 CSW, supra note 26. 
violations in recent years. ${ }^{30}$ The Setara Institute's latest report on freedom of religion or belief documents 270 incidents of religious intolerance and 208 incidents of violations of freedom of religion or belief in 2016, an increase on previous years. ${ }^{31}$ The Setara Institute notes that the politicization of religion, particularly surrounding the recent Jakarta gubernatorial election, has contributed to an increasingly intolerant atmosphere for religious minorities. ${ }^{32}$

At the heart of the issue are extreme groups such as the Front Pembela Islam (FPI) and Hizbut-Tahrir who are promoting a fundamentalist view of Islam which excludes moderates and denounces non-Muslims. Funding from Saudi Arabia has helped spread of Wahhabi-Salafi ideas, leading to a rise in intolerance particularly evident in Aceh, but discernible throughout Indonesia. ${ }^{33}$ The rise of an increasingly conservative ideology within civil society provided the momentum and the energy for Ahok's blasphemy case, and this ideology fuels the hate speech and violence against Christians and other religious minorities which is taking place across the nation.

\section{a. Ahok's Blasphemy Case}

On 9 May 2017, the governor of Jakarta, Basuki Tjahaja Purnama, known as 'Ahok', was found guilty of blasphemy and sentenced to two years in prison. This followed his defeat in the final round of the gubernatorial election in Jakarta on 19 April. ${ }^{34}$

The case dates back to 27 September 2016, when Ahok reportedly quoted a Qur'anic verse on the campaign trail while addressing concerns that his political opponents may use the verse to discourage people from voting for him as a nonMuslim. He was then falsely accused of criticising the verse itself. The court case against the governor was filed by several conservative Islamic groups after his statement went viral via a doctored YouTube video.

On 13 November 2016, Ahok was formally charged with blasphemy and his trial began on 13 December 2016. An estimated 500,000 Muslims turned up to a number of rallies in November and December 2016 to protest against his supposed blasphemy. ${ }^{35}$

30 Fachrul Sidiq, "Violations of religious freedom increase in 2016: Komnas HAM", (10 January 2017), online: Jkt Post <http://www.thejakartapost.com/news/2017/01/10/violations-of-religious-freedomincrease-in-2016-komnas-ham.html>.

31 Marguerite Afra Sapiie, "Government inaction creates space for rising intolerance in Indonesia", (1 February 2017), online: Jkt Post <http://www.thejakartapost.com/news/2017/02/01/government-inactioncreates-space-for-rising-intolerance-in-indonesia-.html $>$.

32 Setara Institute, Intolerance Supremacy: The report of Condition of Freedom of Religion or Belief and Religious Minorities in Indonesia in 2016 (Setara Institute, 2017).

33 Krithika Varagur, "Saudi Arabia Quietly Spreads its Brand of Puritanical Islam in Indonesia", (17 January 2017), online: $V O A$ <https://www.voanews.com/a/saudi-arabia-quietly-spreads-its-brand-ofpuritanical-islam-in-indonesia-/3679287.html>.

34 Kate Lamb, "Jakarta governor Ahok sentenced to two years in prison for blasphemy", The Guardian (9 May 2017), online: <http://www.theguardian.com/world/2017/may/09/jakarta-governor-ahok-foundguilty-of-blasphemy-jailed-for-two-years>.

35 Indra Budiari, "Anti-Ahok rally ends peacefully", (2 December 2016), online: Jkt Post <http://www.thejakartapost.com/news/2016/12/02/anti-ahok-rally-ends-peacefully.html>. 
Ahok was a symbol of Indonesia's pluralism. As an ethnic Chinese and a Christian serving as Governor of the capital of the world's largest Muslim-majority nation, he was an advertisement for Indonesia's religious and ethnic diversity and tolerance. Furthermore, he was also a popular and respected governor, with a reputation for tackling corruption and improving public services. Although religion was not the only factor in the attempts to bring him down, it was used as a political card by his opponents, who campaigned from mosque to mosque on the message that Muslims should not vote for a non-Muslim. Anies Baswedan, who won the election, built a coalition of supporters that includes radical Islamist groups such as the vigilante FPI, thus empowering and emboldening extremists and providing them with a platform.

Indonesia's religious minorities have been shaken by Ahok's imprisonment. If a popular governor, close to the President, respected for tackling corruption and introducing significant improvements in public services, can be brought down and jailed on the grounds of religion, what is the future for Indonesia's ordinary Christians, Buddhists, Hindus, Ahmadiyya or Shi'a Muslims, or indeed for the courageous voices of moderation among the Sunni Muslim population? The emboldened extremists must be tackled head-on by the government and civil society.

\section{b. The Ahmadiyya}

The Ahmadiyya Muslim community has existed in Indonesia since 1925, and claims a population of approximately 500,000, across 330 branches throughout the country. The Ahmadiyya consider themselves to be Muslims, but are regarded by some other Muslims as heretical. Since 2005, as Indonesia's Islam has taken on a more hard-line tone, they have experienced serious violations of freedom of religion or belief, including incidents of violence, and since 2008 a Joint Ministerial Decree introduced by the Minister of Religious Affairs, the Attorney General and the Minister of Home Affairs has imposed a prohibition on any promulgation of Ahmadiyya teachings. In 2011, the then Minister of Religious Affairs repeatedly called for an outright ban on the Ahmadiyya, and in 2013 the Governor of West Java said that there would be no violence against the Ahmadiyya if there were no Ahmadiyya teachings or practices, which he described as "a deviant belief". The "problem", he added, "will disappear if the belief disappears". ${ }^{36}$

I recently met representatives of the Ahmadiyya community in Bekasi, Depok, Bandung, Yogyakarta and at the community's national headquarters in Bogor. Although there has been "some improvement" under the government of President Joko Widodo, intimidation of the Ahmadiyya continues. One representative told me that the community now enjoys a good relationship with the Minister of Religious Affairs, other ministers and the Chief of Police in Jakarta, but argued that there is a need for the security forces to receive human rights education so that they can better protect and respect the rights of religious minorities. Ahmadiyya activities continued to be restricted,

36 Farouk Arnaz \& Vento Saudale, “Another Ahmadiyah Mosque Sealed in West Java”, (7 May 2013), online: Jkt Globe <http://jakartaglobe.id/news/another-ahmadiyah-mosque-sealed-in-west-java/ . 
with some gatherings prohibited, particularly for the birthday of the Prophet Mohammed.

\section{c. Christians in Aceh Singkil}

In October 2015 Christians in Aceh Singkil regency came under severe pressure, with demands for churches to close. Violent clashes broke out after a demonstration on 6 October by an Islamic youth group demanding that the local government tear down a number of churches that they claimed had been built illegally without permits. They threatened to tear down the churches themselves if their demands were not met. On 13 October 2015 one man was killed and a church burned down in violent clashes, even though the local government had already agreed to demands by extremists to close 13 churches in the area and force the churches to register for new permits. They also decided to force the Christian community to adhere to a 1979 agreement which stated that only one church and four chapels can be built in Aceh Singkil. However, the group took matters into their own hands. After the first church was burned down, they clashed with Christians at another church. The police and the military were deployed to restore order and the attack on the churches was condemned by President Joko Widodo. On 21 October in Aceh Singkil, a Protestant Christian Church of Pakpak Dairi (GKPPD) church and a chapel, Undung-undung Katolik Desa Mandumpang, were destroyed by the government. ${ }^{37}$

In May 2017 I met a pastor in a remote location in North Sumatra. He told me that he had been born in Aceh Singkil, and ordained as a pastor in 2006. In 2015, following the attacks on churches, he had to flee because he was receiving constant, numerous and severe threats on social media and on posters erected in the area. The threats began on 10 October 2015, three days before the attacks on churches. On 12 October, the day before the attacks, he received a letter and a video from someone who had attended a meeting of extremists demanding his death. Subsequently an attempt was made to attack him in the street. A price was placed on his head, with a reward of 100 million Indonesian Rupiah (\$7500) for anyone who captured him, dead or alive. He was targeted because he was the leader of his denomination, and because he was the only Acehnese-born pastor, so he became a representative of local Christians and a vocal defender of human rights. With the death threats mounting, his denomination decided to evacuate him. His wife and three children, and his parents, were evacuated separately and they were separated for over a week. "My children were very traumatized," he said. "My daughter was very frightened and asked me many times to give up my ministry." Another pastor confirmed this. "I helped evacuate them. His wife asked many times what would the future hold. She was very frightened. Every time a car comes, she is afraid, wondering whether it is the police or the FPI. They are traumatized."

This pastor and his family remain in a safe location and have not returned to Singkil. "The threats make me too worried to return," he told me. "I feel insecure. My parents are still there and they feel under pressure, worried, because the hardliners spread rumours that I have been killed or kidnapped. The response of the authorities is

37 "One dead and church burned in Aceh - Christian Solidarity Worldwide", (15 October 2015), online: 〈https://www.csw.org.uk/2015/10/15/news/2815/article.htm〉. 
not reassuring. Our dilemma is if we report such threats to the police, they may provide information to the hardliners. The police might reveal my location to them. Sometimes the government invites me to meet them, but I feel it is threatening."

The pastors in North Sumatra described the wider atmosphere in Aceh Singkil, claiming that the religious police "control everyone's lifestyle", requiring Christian women, as well as Muslim women, to wear the jilbab (or 'hijab', headscarf). "Implementation of sharia is supposed to be only for Muslims," said one pastor, "but in the last three years Sharia has also been targeting Christians, so we really feel threatened. How long should we stay in Aceh, or should we leave?"

On 27 September 2014, Aceh's parliament approved bylaws that extend sharia to non-Muslims. This has led to a variety of violations of freedom of religion or belief, including mandating lashes for women who dress 'immodestly', people who drink too much alcohol, or have sex outside of marriage. ${ }^{38}$ More than twenty churches and Buddhist temples have been closed since 2012.39 On 13 March 2017 two Buddhists were whipped for gambling. ${ }^{40}$

\section{d. Concluding thoughts: The situation in Yogyakarta}

Yogyakarta used to be known as the "City of Tolerance", but without exception everyone I spoke to during a visit to Yogyakarta claimed it has long since ceased to merit that title. "The wave of intolerance is very strong in Yogyakarta," said one Christian pastor.

A few days after Ahok's sentencing, a 15-year-old Christian school girl received a telephone call from her best friend, a 15 year-old Muslim girl. The two teenagers were close friends and studied together at what was described as "the most tolerant high school in Yogyakarta. Yet the Muslim girl told her Christian friend: "We can no longer be friends." When asked why, she replied: "My God does not allow me to be friends with people like you." If this occurs in a high school with a reputation for tolerance, in a city with a tradition of tolerance, it is a sign of how widespread the rise of extremism and intolerance has become.

According to one pastor, it is now "almost impossible" to build a new church in Yogyakarta. "Every new church would be rejected by society. Many churches have closed. The intolerant groups monitor church activities. They have spies in churches everywhere, every week. It is very dangerous."

Even to repair a church or build an extension or a new building on existing church property is now impossible without permission, the pastor claimed. "The problem is, our church is very fast-growing because there are many students at universities in the city, but they have nowhere to meet and pray in the university. So, they come to

38 Jon Emont, "As Shariah Experiment Becomes a Model, Indonesia's Secular Face Slips", $N$ Y Times (20 January 2018), online: <https://www.nytimes.com/2017/01/12/world/asia/indonesia-sharia-lawaceh.html>.

39 CSW, supra note 26 at 57-58.

40 Hotli Simanjuntak \& Moses Ompusunggu, "Buddhists caned for violating sharia in Aceh", (13 March 2017), online: Jkt Post <http://www.thejakartapost.com/news/2017/03/13/buddhists-caned-violatingsharia-aceh.html>. 
church. We have 6000 members. But we are not allowed to repair the church, so eventually the church will fall down."

Even moderate Muslims in Yogyakarta in the influential Nadhlatul Ulama (NU) organization are threatened, he claims. "Two months ago, at an inter-faith meeting with a speaker from NU, the radicals threatened the speaker and asked to stop the meeting. Two of the most respected kyais [Islamic scholars] from NU talked about Yogyakarta as a City of Tolerance and the radicals protested and threatened them. If NU, the majority, is in danger, imagine how it is for the minorities."

Islamist fundamentalism has put Indonesia's pluralism in peril. "It's over for Indonesia's tradition of moderation," Andreas Harsono, Human Rights Watch's researcher in Jakarta told me. "In ten years, Indonesia could be Pakistan. No bars, no beer, very limited rights for minorities, and women completely covered, especially in the most conservative Muslim areas. And there might be big violence."

\section{REJECTING RELIGIOUS INTOLERANCE: APPLYING THE RABAT PLAN OF ACTION TO THE SITUATION IN MYANMAR AND INDONESIA}

Religious intolerance in Myanmar and Indonesia is driven by extreme ideologies which reject tolerance and diversity. These ideologies influence society and generate a culture of discrimination. To challenge the pervasive influence of intolerance, a variety of imaginative strategies are necessary. The Rabat Plan of Action provides a path forward.

In 2011, the Office of the United Nations High Commissioner for Human Rights (OHCHR) organized a series of expert workshops on incitement to national, racial or religious hatred. ${ }^{41}$ The outcome of these meetings, attended by the Special Rapporteur on freedom of religion or belief, was the Rabat Plan of Action. The Rabat Plan of Action provides an innovative approach to tackling the problem of national, racial and religious hatred. Although it provides some legislative recommendations, the majority of proposals focus on so-called 'soft policy', rather than hard law. By encouraging governments not only to legislate, but also to exert their cultural influence to tackle hate speech, the Rabat Plan of Action provides a road-map for combatting religious hatred.

The relevant recommendations of the Rabat Plan of Action can be split into four sections, all of which have application to the situation in Myanmar and Indonesia. Softpolicy recommendations are made to States, and 'other stakeholders'. ${ }^{42}$ Recommendations focusing on jurisprudence and legislation are also made to States. This paper will consider the application of each of these key sets of recommendations in turn.

1. Recommendations to States relating to Government Policies (particularly nonlegislative policy)

41 OHCHR |, "Rabat Plan of Action on the prohibition of advocacy of national, racial or religious hatred that constitutes incitement to discrimination", online: <http://www.ohchr.org/EN/Issues/FreedomReligion/Pages/RabatPlanOfAction.aspx>.

42 Ibid. 
Culture drives hate crime. This is the key conclusion which governs the recommendations relating to government policy found in the Rabat Plan of Action, and we see its truth played out in Myanmar and Indonesia. Legislation is only part of the wider tool-kit available to states where hate crime is a problem. Action on all fronts is needed to tackle the threat of religious and racial intolerance. In the words of the Rabat Plan, 'any related legislation should be complemented by initiatives from various sectors of society geared towards a plurality of policies, practices and measures nurturing social consciousness, tolerance and understanding change and public discussion. ${ }^{43}$ Tackling the root causes of intolerance requires more than just legislation. A 'broader set of policy measures is needed, for example in the areas of intercultural dialogue..., education on pluralism and diversity, and policies empowering minorities. ${ }^{44}$

The Rabat Plan recommends action in a number of areas where the state has power: it can promote minority voices through media organisations, it can establish and solidify the mandate of national human rights organisations and it can work to strengthen civil society. It recommends that states should raise the capacity to train and sensitise the security forces, law-enforcement agents and those involved in the administration of justice regarding questions concerning the prohibition of incitement to hatred. ${ }^{45}$ It goes on to suggest that training on human rights values and tolerance be incorporated into the school curriculum and that negative stereotyping be tackled at all levels of culture. Initiatives which promote inter-cultural understanding, including interfaith initiatives, are encouraged.

Ever since the violence in Rakhine State in 2012 and in Meikhtila in 2013, some have been persistently urging the government of Myanmar and the international community to take meaningful steps to tackle religious hatred, with only limited success. In 2014, a year on from Meikhtila's tragedy, the European Burma Network (EBN) - an alliance of human rights groups across Europe - expressed concern that little was being done to tackle hate speech in Myanmar. ${ }^{46}$ The EBN urged the then government to study the Rabat Plan of Action, a UN document detailing way to tackle religious intolerance, and to examine the recommendations of the UN Special Rapporteur on freedom of religion or belief on hate speech. The EBN called on the international community to significantly increase funding for initiatives that promote inter-faith harmony and understanding and counter intolerance. The EBN recommended a highlevel international conference, to be held in Myanmar, to bring together representatives of different religions, civil society groups and political groups, with international experts, to consider how to address Myanmar's growing religious intolerance. "Unless greater priority is given to tackling this growing problem," warned the EBN, "we fear that

43 OHCHR, Annual report of the United Nations High Commissioner for Human Rights, Report of the United Nations High Commissioner for Human Rights on the expert workshops on the prohibition of incitement to national, racial or religious hatred A/HRC/22/17/Add.4 (2013) at 12.

44 Ibid.

45 Ibid at 13.

46 Burma Campaign UK, "Religious freedom must be central to Burma's democratization", (27 January 2014), online: Burma Campaign $U K$ <http://www.burmacampaign.org.uk/religious-freedom-must-becentral-to-burmas-democratisation/>. 
further violence and more laws and other policies which persecute and discriminate against religious and ethnic minorities in Burma are inevitable.”

In 2015, the Special Rapporteur on the human rights situation in Myanmar recommended that the government 'take urgent steps to address escalating extremist nationalism, with government officials speaking out against instances of hate speech. ${ }^{47}$ The Rabat Plan of Action provides avenues through which they can do this, and in a positive sign that the government is taking this recommendation on, the Religious Affairs Ministry has strongly critiqued Ma Ba Tha over the past year. ${ }^{48}$ Further action in response to hate preaching is needed in order to better curtail religious intolerance. To start, the government must take steps to enforce the recent ban on Ma Ba Tha.

The education system continues to be biased, and Chin Christians are forced to attend $\mathrm{Na} \mathrm{Ta}$ La schools where they are forced to convert. The government must put tolerance at the heart of the curriculum, teaching Myanmar's every citizen about the positives of Myanmar's ethnic diversity - promoting a truly rainbow nation.

The Rabat Plan of Action could also provide a road-map for the Panglong Peace talks. The government should seriously consider the recommendation of establishing a truth and reconciliation commission, and recommendations about the education of the military. The Tatmadaw continue to be major perpetrators of religious freedom violations, their re-education must be an urgent priority as their actions fuel violence and religious hatred.

Recommendations from the Rabat Plan should be taken into account as the government attempt to tackle the Rohingya crisis. Although she has been widely criticised for failing to do more, one step Aung San Suu Kyi has taken is to establish a commission led by former UN Secretary-General Kofi Annan, to find solutions to the Rohingyas' plight. Many of the recommendations of the Annan Commission's interim report could be taken straight from the Rabat Plan of Action, and it is pleasing to hear that Aung San Suu Kyi has accepted these recommendations going forward. ${ }^{49}$ The Commission recommends that the military should 'as an urgent measure' ensure 'comprehensive training for police and other security forces deployed in Rakhine, covering areas such as human rights and respect for cultural and religious diversity. ${ }^{50}$ It continues to highlight that inter-communal dialogue must be a priority both at the Union and State level, calling on the 'Government of Myanmar' to 'proactively dispel misinformation about different communities', and to 'forcefully denounce all kinds of hate speech, and hold perpetrators to account. ${ }^{51}$ The majority of the Commission's recommendations are 'soft-policy' recommendations, akin to those in the Rabat Plan. They serve to underline the importance of this type of policy if Myanmar's troubles are to be overcome.

47 OHCHR, Report of the Special Rapporteur on the situation on human rights in Myanmar (2015).

48 Lawi Weng \& Pyay Kyaw, "Religious Affairs Minister Says No Monk is Above the Law", (14 July 2016), online: The Irrawaddy <https://www.irrawaddy.com/news/burma/religious-affairs-minister-saysno-monk-is-above-the-law.html>.

49 Rakhine Commission, Interim Report and Recommendations (Advisory Commission on Rakhine State, 2017).

50 Ibid at 10.

51 Ibid at 14 . 
This type of soft-policy is similarly important for Indonesia today. The Ahok blasphemy case highlights the presence of an increasingly influential group of people in Indonesia who are promoting religious intolerance for political gains. As has already been described, this has had influence beyond Ahok himself: Indonesia's reputation for tolerance is on the line. It is important to commend President Joko Widodo's government for their fledgling efforts at this. There has been a change in tone, attitude and approach compared with the administration of President Susilo Bambang Yudhoyono. President Widodo has distanced the government from the radical Islamists, attempted to remove some of the previous government's apparent complicity with intolerant groups, and in recent months announced an intention to ban the activities of the Islamist group Hizb-ut-Tahrir and to establish a presidential unit to strengthen and protect the 'Pancasila', Indonesia's state ideology which provides for religious pluralism. ${ }^{52}$ These efforts should be developed so that the tolerant centre is strengthened to withstand attacks from radical Islamists. The ideology of Pancasila must continue to be a central part of the curriculum, and inter-faith dialogue should be encouraged.

\section{Recommendations to other stakeholders relating to non-legislative policy}

After making non-legislative recommendations to government stakeholders, the Rabat Plan of Action presents a number of similar recommendations to 'other stakeholders' ${ }^{53}$ These recommendations are detailed below:

a. Non-governmental organisations, national human rights institutions as well as other civil society groups should create and support mechanisms and dialogues to foster intercultural and inter-religious understanding and learning.

b. Political parties should adopt and enforce ethical guidelines in relation to the conduct of their representatives, particularly with respect to public speech.

c. Self-regulation, where effective, remains the most appropriate way to address professional issues relating to the media

d. Media should, as a social and moral responsibility, play a role in combating discrimination and promoting intercultural understanding by: Taking care to report in context and in a factual manner; Being alert to the danger of discrimination or negative stereotypes being promoted by the media; avoid unnecessary references to race or religion which may promote intolerance; raise awareness of the harm caused by discrimination; reporting on different groups or communities and giving their members an opportunity to speak and to be heard in a way that promotes a better understanding of them, while at the same time reflecting the perspectives of those groups or communities.

These recommendations to civil society and the media are applicable in both Myanmar and Indonesia.

52 Haeril Halim, "Jokowi inaugurates chief, advisors of Pancasila working unit", online: Jkt Post <http://www.thejakartapost.com/news/2017/06/07/jokowi-inaugurates-chief-advisors-of-pancasila-workingunit.html>.

53 OHCHR, supra note 43 at 14-15. 
The Rabat Plan of Action's recommendations to the media must be urgently applied in Myanmar. The state-run media contributes to the culture of hatred through biased reporting. During the crackdown on Rakhine State in 2016, the state-run Global New Light of Myanmar wrote solely about the 'terrorist attack' against Buddhist border guards on 9 October 2016 without referencing human rights violations against Rohingya in Rakhine. ${ }^{54}$ Its editorials and opinion pieces accused foreign journalists of working 'hand in glove' with terrorists and have suggested that Rakhine State's Muslim community is a 'thorn' that has 'to be removed' and its members are 'detestable human fleas'. ${ }^{55}$ Meanwhile the Myanmar Times was forced in November 2016 to stop covering events in Rakhine State after reporting on human rights abuses and two Kachin Christians were arbitrarily detained on 24 December 2016 by the military after speaking to journalists about the destruction of a Catholic Church in Mong Ko. ${ }^{56}$ The Myanmar government must adhere to calls in the Rabat Plan of Action and use its soft power to change this destructive narrative, but the media must also pay attention to the Rabat Plan's call to 'self-regulate and recognise its social and moral responsibility to promote the impartial truth and intercultural understanding'.

Civil society groups must do their utmost to promote inter-ethnic and inter-faith harmony. The strength of Buddhist nationalism in Myanmar is so widespread and influential that the voices of moderation and peace are rare. Some civil society activists are involved in inter-faith dialogue initiatives and advocacy for freedom of religion or belief, and some Buddhist monks are working to counter the hate-filled Buddhist nationalism, but they themselves are threatened and vulnerable.

There is still hope. A positive recent development saw the Buddhist authorities ban $\mathrm{Ma} \mathrm{Ba}$ Tha. ${ }^{57}$ Religious authorities and civil society organisations have the power to change the narrative. The grip of extremists over civil society is far from absolute, and their voice is that of a loud minority, not that of the majority. The Centre for Peace and Conflict Studies conducted interviews with the people living in areas where intercommunal violence took place in 2012-13 found that the vast majority of respondents emphatically exclaimed disowned violence, saying: 'This is not who we are.' 58 The tolerant centre exists in Myanmar, so is time for more concerted action.

Positive initiatives also exist, but it is up to the media and wider civil society to ensure that they are well publicised and celebrated. The Seagull is one example of an initiative promoting human rights and pluralism in Myanmar today. Founded by Harry

54 See chapter on Rakhine State;

55 Htun Khaing, "The NLD's new chapter in propaganda", (31 January 2017), online: Front Myanmar <https://frontiermyanmar.net/en/the-nlds-new-chapter-in-propaganda>.

56 Lun Min Mang, "Two Mong Koe church leaders transferred to Muse police custody”, (26 January 2017), online: Myanmar Times <https:/www.mmtimes.com/national-news/24694-two-mong-koe-churchleaders-transferred-to-muse-police-custody.html $>$.

57 RFA, "Buddhist Authorities Ban Myanmar's Ultranationalist Ma Ba Tha Group", (23 May 2017), online: Radio Free Asia <https://www.rfa.org/english/news/myanmar/ban-05232017152958.html>.

58 Centre for Peace \& Conflict Studies (CPCS), "This is Not Who We Are: Listening to communities affected by communal violence in Myanmar", (September 2015), online: Cent Peace Confl Stud <http://www.centrepeaceconflictstudies.org/publications/browse/8288-2/>. 
Myo Lin, a Muslim, and Ashin Zaya Ditha, a Buddhist, the Seagull advocates for human rights and fosters inter-faith dialogue for peace.

Another courageous voice for human rights, including the rights of religious minorities, is Myanmar's Cardinal Charles Bo, who weaves into almost every homily, regular public statements and articles messages defending human dignity for all the peoples of Myanmar. He describes the suffering of the Rohingyas as "an appalling scar on the conscience of my country", and recently convened an interfaith peace conference of religious leaders to address the ethnic conflict in the rest of Myanmar. Pope Francis has spoken out several times for the Rohingya, recently calling them a "good and peaceful people who have suffered for years". In 2017 the Vatican and Myanmar established formal diplomatic relations, which - it is hoped - will provide the Church with new, better and more formal channels through which to raise its voice of concern, and to encourage the government to protect human rights. In November 2017 Pope Francis became the first Pope ever to visit Myanmar, and although he did not refer to the Rohingyas by name in country, he gave a clear message of peace, religious freedom and human rights in all his speeches and homilies, and then met Rohingya refugees when we visited Bangladesh

In February 2015, Christian Solidarity Worldwide organized the MyanmarIndonesia Interfaith Exchange which drew together civil society activists from both countries. Drawing together Muslims who promote tolerance in Indonesia, and Buddhists with similar aspirations from Myanmar, the initiative aimed to strengthen the efforts of civil society groups in their bid to tackle intolerance. "This trip brought us many advantages," said the Venerable Seindida, Abbot of the Asia Alinyang Monastery at Pyin Oo Lwin. 59 "We were able to learn more about the Muslim majority in Indonesia and about religious minorities and had a chance to learn about their situation firsthand. We met many organisations and people working on peace. In particular, we met with Indonesia's Ministry of Religious Affairs - such a meeting would not be possible in Myanmar," he said.

Venerable Seindida described as "inspiring" the group's dialogue with the Forum for Inter-Religious Harmony in Jakarta, which included meeting members of former Indonesian president Abdurrahman Wahid's family. "Meeting the Wahid family is very different from meeting the sons or daughters of leaders in Myanmar; we would really like them to follow the example of the Wahid family, and work for peace," he said.

The reason that example of civil society in Indonesia inspired counterparts in Myanmar is because the movement for tolerance in Indonesia is more well-established and has greater backing. The Nahdlatul Ulama, the largest independent Islamic organisation in Indonesia, with over 40 million members, are strong advocates of Pancasila and for a tolerant future for Indonesian Islam. They work with the Communion of Churches in Indonesia (PGI) and other religious groups to promote tolerance and harmony. Their size and influence is far greater than that of the extremist voices, yet they have struggled to counter the aggression of FPI and others. The Rabat

59 Marc Jacob, "Interfaith visit to Indonesia", online: <http://archive-

3.mizzima.com/opinion/features/item/18578-interfaith-visit-to-indonesia/18578-interfaith-visit-toindonesia>. 
Plan's call for the establishment of 'support mechanisms and dialogues to foster intercultural and inter-religious understanding and learning' is vital at this critical juncture. It is possible that the Ahok case has been a wake-up call for those who advocate for moderation in Indonesia. It appears that there are increased efforts to promote toleration. The Wahid Foundation have found that in the face of rising religious freedom violations, there has been a rise in attempts to foster communal solidarity ${ }^{60}$

In both Myanmar and Indonesia, civil society and the media will be a central part of any unified action which aim to tackle the culture of hate speech. The Rabat Plan provides a helpful reference point for these groups as they consider how to act.

\section{Recomendations relating to Jurisprudence}

Alongside 'soft-policy' recommendations, the Rabat Plan of Action formulates a number of recommendations to governments about how Jurisprudence can best challenge the threat posed by hate-speech and extremism.

The report concludes that if hate speech is to be effectively undermined, an independent, impartial judiciary which operate alongside independent national human rights institutions is necessary. ${ }^{61}$ Cases of incitement are rarely referred to judicial mechanisms, particularly if victims are from disadvantaged or vulnerable groups. The central importance of an independent judiciary which holds the perpetrators of crimes to account is underlined. States are called to keep national and regional courts regularly updated on international human rights standards and guidance on hate speech. They are further recommended to ensure that independent and impartial tribunals are established which will ensure that a 'fair and public' hearing is given to complainants.

These recommendations must be urgently heeded in Myanmar and Indonesia. Ahok's recent sentencing brought into focus the fact that even Indonesia's judiciary is under threat from the influence of Islamists. The verdict was no surprise - blasphemy cases have a 100 percent conviction rate in Indonesia, and it would have been politically explosive to acquit him. But the severity of the sentence shocked many, especially as the prosecutors had requested probation rather than prison for Ahok. Ahok's defence lawyer complained that the sentence was politically driven: "We respect the decision but we can't accept it. We understand the pressure surrounding this case, but we're disappointed. We will file an appeal to challenge the decision," Ahok's lawyer, I Wayan Sidarta, said. ${ }^{62}$ If Joko Widodo's government hope to be able to challenge hate speech and the threat posed by Islamism in Indonesia, they must ensure that the judiciary preserves its independence and does not buckle under pressure from the radicals.

The Rabat Plan's jurisprudence recommendations carry similar force in the case of Myanmar. While the perpetrators of violence or hate crimes against Muslims or ethnic

60 Aritonang, supra note 2.

61 OHCHR, supra note 43 at 10-11.

62 Callistasia Anggun Wijaya, “Ahok's sentence politically driven: Lawyer”, (9 May 2017), online: Jkt Post <http://www.thejakartapost.com/news/2017/05/09/ahoks-sentence-politically-driven-lawyer.html>. 
minorities in Myanmar are liable to being given lighter sentences, the law-courts and government appear to have focused their attention on stamping out criticism of the government. ${ }^{63}$ The government of Myanmar must prioritise judicial reform so that the regional and national courts properly and impartially implement legislation, ensuring that those who suffer grievous human rights abuses are held to account. The recent death of prominent constitutional lawyer and reformer $\mathrm{U}$ Ko Ni shows how far there is to go. ${ }^{64}$ The Myanmar government must prioritise providing legal assistance for those from minority groups, and they should consider placing civil, or even criminal, sanctions on members of $\mathrm{Ma} \mathrm{Ba}$ Tha, $\mathrm{U}$ Wirathu as a notable example, who are the worst perpetrators of hate speech.

Recommendations relating to legislation

Although the Rabat Plan of Action does not focus on legislation, it does emphasise that legislation plays a role in the creation of a culture of hatred and therefore should be amended accordingly. ${ }^{65}$ It is underlined that 'hate speech' laws ought to prohibit incitement to hatred, but must not be overly vague as vague laws are open to abuse. Blasphemy laws are subject to particular criticism on this count. It is impermissible under international law for laws to 'discriminate in favour of or against one or certain religions or belief systems', and yet the nature of blasphemy laws mean that they tend to favour the majority religion.

This criticism of blasphemy laws could be levied at both Myanmar and Indonesia. Ahok's case is one of a number of recent blasphemy cases. The Setara Institute report that of the 97 blasphemy cases brought to court since the law was enacted in 1965, 89 of them have been since $1998 .{ }^{66}$ A lecturer at the prestigious Universitas Indonesia, Ade Amando, was charged in December 2016 for writing on Facebook that: "God is not an Arab. Surely God would be happy if His scripture was read in the dialects of Minang, Ambon, China, Hip-hop, blues..." ${ }^{\prime 7}$ He could face up to 11 years in jail on two charges, under the blasphemy law and the Information and Electronics Transaction Act. Three leaders of a spiritual movement known as 'Gafatar' are currently on trial for blasphemy in East Jakarta District Court. For the first time, a prominent Islamist leader, Rizieq Shihab, who leads the FPI, which is responsible for violent attacks on religious minorities and many church closures, has also been charged with defamation of the

63 See Human Rights Watch's work on the Telecommunications Law for more on this; e.g. Human Rights Watch (HRW), "Burma: Letter on Section 66(d) of the Telecommunications Law", (10 May 2017), online: Hum Rights Watch <https://www.hrw.org/news/2017/05/10/burma-letter-section-66dtelecommunications-law>.

64 CSW, "CSW condemns assassination of lawyer U Ko Ni - Christian Solidarity Worldwide", (31 January 2017), online: <https://www.csw.org.uk/2017/01/31/news/3443/article.htm>.

65 OHCHR, supra note 43 at 8-10.

66 Setara Institute, “Calls in Indonesia For Repeal of Blasphemy Law”, (10 May 2017), online: Setara Inst <http://setara-institute.org/en/english-calls-in-indonesia-for-repeal-of-blasphemy-lawp>.

67 Coconuts Jakarta, "Universitas Indonesia lecturer formally named blasphemy suspect for writing "God is not an Arab" on FB"”, Coconuts Jkt (25 January 2017), online:

$<$ http://jakarta.coconuts.co/2017/01/25/universitas-indonesia-lecturer-formally-named-blasphemy-suspectwriting-god-not-arab-fb>. 
Pancasila and blasphemy. Rizieq Shihab is one of the most prominent leaders of the campaign against Ahok. ${ }^{68}$

In Myanmar, the Section 295 (a) of the Penal Code is a 'blasphemy law' and is used to prosecute people who are deemed to have insulted Buddhism. Legitimate acts of expression are deemed to insult religion and open to prosecution. For instance, in 2015, Philip Blackwood and colleagues, Tun Thurein and Htut Ko Ko Lwin were jailed for two and a half years with hard labour for posting a psychedelic image of the Buddha wearing headphones in order to promote their bar. ${ }^{69}$

The law contributes to discrimination because of biases in the judiciary. Statements offensive to religious minorities have gone unpunished while false evidence against minorities has been accepted as legitimate. Htin Linn Oo, a writer and NLD info officer was sentenced to two years in prison with hard labour in 2015. The basis for the blasphemy charge against him was a speech of his which had been tampered and edited in a way which made it appear hostile to Buddhist nationalism. The charges against a moderate Buddhist who had the nerve to raise important questions about Buddhist nationalism illustrate the damage that blasphemy laws can cause when extremists control the judiciary. ${ }^{70}$

It is concerning to note that $\mathrm{Ma} \mathrm{Ba}$ Tha activists believe that the punishment for blasphemy is insufficient and are demanding a tougher punishment in order to 'control the spread of Islam'. The law itself breaks both international law and Myanmar's own constitution. It leaves minorities vulnerable to baseless accusations. It should be eradicated, not strengthened. ${ }^{71}$

Blasphemy laws in many countries lead to people being jailed or killed. Such laws are frequently misused to pursue vendettas unrelated to religion - in the case of Ahok, there is little doubt of the political motivation behind the decision to charge him with blasphemy, contributing to his defeat in the recent gubernatorial elections. My colleagues at the human rights organisation Christian Solidarity Worldwide and I have advocated for years for the repeal of such laws. ${ }^{72}$ The Rabat Plan of Action's call should be heeded by the governments of Myanmar and Indonesia.

\section{CONCLUSION}

68 Agence France-Presse, "Indonesia police accuse Muslim hardliner of defaming founding president Sukarno", The Guardian (31 January 2017), online: <http://www.theguardian.com/world/2017/jan/31/indonesia-police-accuse-muslim-hardliner-of-defamingfounding-president-sukarno>.

69 Vani Sathisan, Sanhita Ambast \& Reema Omer, "Blasphemy statutes deny human rights", online: Myanmar Times <https://www.mmtimes.com/opinion/15579-blasphemy-statutes-deny-humanrights.html>.

70 Ibid.

71 Ibid.

72 Benedict Rogers, "As A Christian, I Stand In Solidarity With Stephen Fry - Blasphemy Laws Are Wrong, Dangerous And Should Be Repealed", (8 May 2017), online: HuffPost UK <http://www.huffingtonpost.co.uk/ben/stephen-fry-blasphemy_b_16485042.html>. 
There are parallels between the assassination of Myanmar's most prominent Muslim lawyer and constitutional expert, U Ko Ni, in front of Yangon Airport in January 2017 and the sentencing of Ahok in Jakarta in May 2017. As a lawyer, U Ko Ni was deeply involved in advocacy for constitutional reform, which was at the heart of the NLD's election campaign in 2015. As Governor of Jakarta, Ahok was well-respected for his campaign against corruption. The two incidents, where religious minority reformers were attacked and harmed by extremists remind us how much work there is to be done in Myanmar and Indonesia. Damaging ideologies are derailing positive progress in both nations, threatening to lead to the destruction of Indonesia's tradition of tolerance and Myanmar's fledgling democracy. If this threat is to be overcome, both government and civil society in Indonesia and Malaysia must heed the calls made in the Rabat Plan of Action. All the tools in the armoury must be mobilised, both soft and hard-policy action so that the tolerant majority can defeat extremism.

Alissa Wahid and Cardinal Charles Maung Bo, two leading advocates for religious tolerance in Indonesia and Myanmar, co-authored an excellent opinion piece for the Wall Street Journal in September 2016 on threats to freedom of religion or belief in South-east Asia. ${ }^{73}$ Embodying the spirit of the Rabat Plan of Action, policy makers and civil society members should listen to their concluding words and respond with action. They wrote:

'Finally, we must speak out for the freedom of religion or belief for all. As Burma's first cardinal and the daughter of Abdurrahman Wahid (Gus Dur), Indonesia's former president and prominent Islamic scholar, the two of us have tried to show by example how important this is. We have spoken out for Burma's Muslims and for Indonesia's Christians when they face discrimination and persecution. We urge the region's religious and political leaders to do the same.'

\section{BIBLIOGRAPHY}

AHRC. "The Constitution of the Republic of Indonesia of 1945", online: Asian Hum Rights

Comm

$<$ http://www.humanrights.asia/countries/indonesia/\%20countries/indonesia/laws/uud1 945_en>.

Altsean-Burma. "Anti-Muslim Violence in Central Burma”, (17 April 2013), online: Burma Partnersh <http://www.burmapartnership.org/2013/04/anti-muslim-violence-incentral-burma/>.

Amnesty International. "MYANMAR: HEALTH CONCERNS FOR PRISONER OF CONSCIENCE: LAHPAI GAM", (7 April 2017), online: Amnesty Int

73 Charles Maung Bo \& Alissa Wahid, "Rejecting Religious Intolerance in Southeast Asia”, Wall StrJ (27 September 2016), online: <https://www.wsj.com/articles/rejecting-religious-intolerance-in-southeast-asia$1474992874>$. 
<https://www.amnesty.org/en/documents/document/?indexNumber=asa16\%2f6029\%2 f2017\&language $=$ en $>$.

Aritonang, Margareth S. "Religious-based discrimination lives on, but more positive initiatives grow: Wah...", (28 February 2017), online: Jkt Post <http://www.thejakartapost.com/news/2017/02/28/religious-based-discrimination-liveson-but-more-positive-initiatives-grow-wahid-foundation.html>.

Arnaz, Farouk \& Vento Saudale. "Another Ahmadiyah Mosque Sealed in West Java”, (7 May 2013), online: Jkt Globe <http://jakartaglobe.id/news/another-ahmadiyahmosque-sealed-in-west-java/>.

Bo, Charles Maung \& Alissa Wahid. "Rejecting Religious Intolerance in Southeast Asia", Wall Str J (27 September 2016), online: $<$ https://www.wsj.com/articles/rejecting-religious-intolerance-in-southeast-asia1474992874>.

Budiari, Indra. "Anti-Ahok rally ends peacefully", (2 December 2016), online: Jkt Post <http://www.thejakartapost.com/news/2016/12/02/anti-ahok-rally-endspeacefully.html>.

Burma Campaign UK. "Religious freedom must be central to Burma's democratisation", (27 January 2014), online: Burma Campaign UK $<$ http://www.burmacampaign.org.uk/religious-freedom-must-be-central-to-burmasdemocratisation/s.

C4DS. "Sticks and Stones: Hate Speech Narratives and Facilitators in Myanmar", online: Burma Partnersh <http://www.burmapartnership.org/2016/02/sticks-andstones-hate-speech-narratives-and-facilitators-in-myanmar $>$.

Centre for Peace \& Conflict Studies (CPCS). "This is Not Who We Are: Listening to communities affected by communal violence in Myanmar", (September 2015), online: Cent Peace Confl Stud <http://www.centrepeaceconflictstudies.org/publications/browse/8288-2/>.

CIA. "CIA World Factbook: Indonesia", (4 June 2018), online: Cent Intell Agency <https://www.cia.gov/ibrary/publications/the-world-factbook/geos/id.html>.

Coconuts Jakarta. "Universitas Indonesia lecturer formally named blasphemy suspect for writing "God is not an Arab" on FB", Coconuts Jkt (25 January 2017), online: $<$ http://jakarta.coconuts.co/2017/01/25/universitas-indonesia-lecturer-formally-namedblasphemy-suspect-writing-god-not-arab-fb>.

CSW. "CSW visit to the Bangladesh-Burma border - Christian Solidarity Worldwide", (26 August 2008), online: <https://www.csw.org.uk/2008/08/26/report/100/article.htm>. 
- "CSW prioritise human rights during Burma trip - Christian Solidarity Worldwide”, (7 December 2012), online: <https://www.csw.org.uk/2012/12/07/news/1366/article.htm>.

—. "Indonesia Report Pluralism in Peril - Christian Solidarity Worldwide", (14 February 2014), online: CSW <https://www.csw.org.uk/2014/02/14/report/179/article.htm>.

- "Report on human rights violations in Rakhine State - Christian Solidarity Worldwide”, (12 January 2017), online: <https://www.csw.org.uk/2017/01/12/report/3423/article.htm>.

—. "CSW condemns assassination of lawyer U Ko Ni - Christian Solidarity Worldwide”, (31 January 2017), online: <https://www.csw.org.uk/2017/01/31/news/3443/article.htm>.

"One dead and church burned in Aceh - Christian Solidarity Worldwide", (15 October 2015), online: 〈https://www.csw.org.uk/2015/10/15/news/2815/article.htm>.

Emont, Jon. "As Shariah Experiment Becomes a Model, Indonesia's Secular Face Slips”, $\quad N \quad Y \quad$ Times $\quad$ (20 January 2018), online: <https://www.nytimes.com/2017/01/12/world/asia/indonesia-sharia-law-aceh.html>.

Fleming, Rachel. Hidden Plight: CHRISTIAN MINORITIES IN BURMA (United States Commission on International Religious Freedom, 2016).

France-Presse, Agence. "Indonesia police accuse Muslim hardliner of defaming founding president Sukarno", The Guardian (31 January 2017), online: <http://www.theguardian.com/world/2017/jan/31/indonesia-police-accuse-muslimhardliner-of-defaming-founding-president-sukarno>.

Halim, Haeril. "Jokowi inaugurates chief, advisors of Pancasila working unit", online: Jkt Post <http://www.thejakartapost.com/news/2017/06/07/jokowi-inaugurates-chiefadvisors-of-pancasila-working-unit.html $>$.

Holmes, Oliver \& agencies. "Nobel laureates warn Aung San Suu Kyi over 'ethnic cleansing' of Rohingya", The Guardian (30 December 2016), online: <http://www.theguardian.com/world/2016/dec/30/nobel-laureates-aung-san-suu-kyiethnic-cleansing-rohingya>.

Human Rights Council. United Nations Rabat Plan of Action A/HRC/22/17/Add.4 (2013).

Human Rights Watch. "Myanmar: Free Wrongfully Detained Kachin Christian Leaders", (25 July 2017), online: Hum Rights Watch <https://www.hrw.org/news/2017/07/25/myanmar-free-wrongfully-detained-kachinchristian-leaders $>$. 
Human Rights Watch (HRW). "Burma: Two Islamic Schools Shuttered in Rangoon", (8 May 2017), online: Hum Rights Watch <https://www.hrw.org/news/2017/05/08/burma-two-islamic-schools-shutteredrangoon>.

—. "Burma: Letter on Section 66(d) of the Telecommunications Law", (10 May 2017), online: Hum Rights Watch <https://www.hrw.org/news/2017/05/10/burma-lettersection-66d-telecommunications-law $>$.

Jacob, Marc. "Interfaith visit to Indonesia", online: <http://archive3.mizzima.com/opinion/features/item/18578-interfaith-visit-to-indonesia/18578interfaith-visit-to-indonesia>.

Khaing, Htun. "The NLD's new chapter in propaganda", (31 January 2017), online: Front Myanmar <https://frontiermyanmar.net/en/the-nlds-new-chapter-inpropaganda>.

Kinetz, Erika. "New Numerology of Hate Grows in Burma", (29 April 2013), online: The Irrawaddy <https://www.irrawaddy.com/news/burma/new-numerology-of-hategrows-in-burma.html>.

Lamb, Kate. "Jakarta governor Ahok sentenced to two years in prison for blasphemy", The Guardian (9 May 2017), online: <http://www.theguardian.com/world/2017/may/09/jakarta-governor-ahok-found-guiltyof-blasphemy-jailed-for-two-years $>$.

Mang, Lun Min. "Two Mong Koe church leaders transferred to Muse police custody", (26 January 2017), online: Myanmar Times <https://www.mmtimes.com/nationalnews/24694-two-mong-koe-church-leaders-transferred-to-muse-police-custody.html>.

McPherson, Poppy. "Myanmar failing to stop spread of religious violence, UN envoy says", The Guardian (19 May 2017), online: <http://www.theguardian.com/world/2017/may/19/myanmar-failing-to-stop-spread-ofreligious-violence-un-envoy-says>.

OHCHR. Annual report of the United Nations High Commissioner for Human Rights, Report of the United Nations High Commissioner for Human Rights on the expert workshops on the prohibition of incitement to national, racial or religious hatred A/HRC/22/17/Add.4 (2013).

OHCHR |. "Rabat Plan of Action on the prohibition of advocacy of national, racial or religious hatred that constitutes incitement to discrimination", online: <http://www.ohchr.org/EN/Issues/FreedomReligion/Pages/RabatPlanOfAction.aspx>.

Pew Research Center. "The Global Religious Landscape: Muslims", (18 December 2012), online: Pew Res Cent Relig Public Life Proj <http://www.pewforum.org/2012/12/18/global-religious-landscape-muslim/>. 
Rakhine Commission. Interim Report and Recommendations (Advisory Commission on Rakhine State, 2017).

- Report of the Special Rapporteur on the situation on human rights in Myanmar (2015).

RFA. "Buddhist Authorities Ban Myanmar's Ultranationalist Ma Ba Tha Group", (23 May 2017), online: Radio Free Asia <https://www.rfa.org/english/news/myanmar/ban-05232017152958.html>.

Rogers, Benedict. “As A Christian, I Stand In Solidarity With Stephen Fry - Blasphemy Laws Are Wrong, Dangerous And Should Be Repealed”, (8 May 2017), online: HuffPost $\quad U K \quad<$ http://www.huffingtonpost.co.uk/ben/stephen-fryblasphemy_b_16485042.html>.

Sapiie, Marguerite Afra. "Government inaction creates space for rising intolerance in Indonesia", (1 February 2017), online: Jkt Post $<$ http://www.thejakartapost.com/news/2017/02/01/government-inaction-creates-spacefor-rising-intolerance-in-indonesia-.html .

Sathisan, Vani, Sanhita Ambast \& Reema Omer. "Blasphemy statutes deny human rights", online: Myanmar Times <https://www.mmtimes.com/opinion/15579blasphemy-statutes-deny-human-rights.html>.

Setara Institute. "Calls in Indonesia For Repeal of Blasphemy Law", (10 May 2017), online: Setara Inst <http://setara-institute.org/en/english-calls-in-indonesia-for-repealof-blasphemy-law $>$.

Setara Institute. Intolerance Supremacy: The report of Condition of Freedom of Religion or Belief and Religious Minorities in Indonesia in 2016 (Setara Institute, 2017).

Sidiq, Fachrul. "Violations of religious freedom increase in 2016: Komnas HAM", (10 January 2017), online: Jkt Post <http://www.thejakartapost.com/news/2017/01/10/violations-of-religious-freedomincrease-in-2016-komnas-ham.html .

Simanjuntak, Hotli \& Moses Ompusunggu. "Buddhists caned for violating sharia in Aceh", (13 March 2017), online: Jkt Post <http://www.thejakartapost.com/news/2017/03/13/buddhists-caned-violating-shariaaceh.html $>$.

_ . "Myanmar Muslims face charges for holding Ramadan prayers", The Guardian (2 June 2017), online: <http://www.theguardian.com/world/2017/jun/02/myanmarmuslims-face-charges-for-holding-ramadan-prayers $>$. 
United Nations. "UN report details 'devastating cruelty' against Rohingya population in Myanmar's Rakhine province”, (3 February 2017), online: UN News $<$ https://news.un.org/en/story/2017/02/550802-un-report-details-devastating-crueltyagainst-rohingya-population-myanmars $>$.

United Nations Data. "UN Data, Indonesia", online: UN Data <http://data.un.org/en/iso/id.html>.

Universal Declaration of Human Rights, United Nations, 1948 [Universal Declaration of Human Rights].

Varagur, Krithika. "Saudi Arabia Quietly Spreads its Brand of Puritanical Islam in Indonesia", (17 January 2017), online: VOA <https://www.voanews.com/a/saudiarabia-quietly-spreads-its-brand-of-puritanical-islam-in-indonesia-/3679287.html>.

Weng, Lawi \& Pyay Kyaw. "Religious Affairs Minister Says No Monk is Above the Law", (14 July 2016), online: The Irrawaddy <https://www.irrawaddy.com/news/burma/religious-affairs-minister-says-no-monk-isabove-the-law.html>.

Wijaya, Callistasia Anggun. “Ahok's sentence politically driven: Lawyer”, (9 May 2017), online: Jkt Post <http://www.thejakartapost.com/news/2017/05/09/ahoks-sentencepolitically-driven-lawyer.html>.

Benedict Rogers is a human rights activist and writer. As East Asia Team Leader at the international human rights organization Christian Solidarity Worldwide (CSW), he specializes in Burma, Indonesia, Malaysia, North Korea and China. He has also worked on East Timor, Pakistan, The Maldives and Sri Lanka in the past. In addition to serving as a Senior Fellow at the Religious Freedom Institute, he is co-founder and Chair of Hong Kong Watch, an Associate of Oxford House, a member of the advisory board of the International Coalition to End Organ Pillaging in China, a Trustee of several charities including the Phan Foundation and the Chin Human Rights Organization, and serves as Deputy Chairman of the Conservative Party Human Rights Commission, which he co-founded in 2005 with Gary Streeter MP, and recently organized their inquiry on China and authored their new report, The Darkest Moment: The Crackdown on Human Rights in China 2013-2016, launched in June 2016. He is the author of six books, including Burma: A Nation at the Crossroads (Random House, 2012) and The Very Stones Cry Out: The Persecuted Church - Pain, Passion and Praise (co-authored with Baroness Cox, Continuum, 2011). 